\title{
ANALISIS FAKTOR YANG BERHUBUNGAN DENGAN KEJADIAN DIARE BALITA DI KELURAHAN KARYAJAYA KOTA PALEMBANG
}

\author{
Rizcita Prilia Melvani $^{1}$, Hilda Zulkifli ${ }^{2}$, Muhammad Faizal ${ }^{3}$ \\ ${ }^{1,2,3}$ Departemen Keselamatan Kesehatan Kerja dan Kesehatan Lingkungan, \\ Magister Kesehatan Masyarakat Fakultas Kesehatan Masyarakat Universitas Sriwijaya \\ Email: rizcitapriliamelvani@yahoo.com ${ }^{1}$, hilda.zulkifli@yahoo.com², \\ muhammadfaizal@yahoo.com ${ }^{3}$
}

\begin{abstract}
Diarrhea is a main problems in developing countries, and it was infected to toddlers including in Indonesia. Based on data of Palembang Health Department, Karya Jaya Village as the most toddlers infected by diarrhea. The objectives of this research, in order to analyse relationship between environmental sanitation facilities and mother's habits towards the diarrhea impacts in Karya Jaya Village Palembang City. This research was conducted in August 2018. The population of this research is all the mothers who have toddlers in Karya Jaya Village, and has taken samples for 60 respondents by using proportional random sampling. This research using quantitative method in which using cross sectional design. Instruments of collecting data using observations, questionnaires, interviews, and multiple logistic regression data analysis. The results showed that there was a relationship between maternal education ( $p=$ $0.012)$, exclusive breastfeeding $(p=0.009)$, food and beverage sanitation hygiene ( $p=$ $0,000)$, to the incidence of toddler diarrhea.
\end{abstract}

Keywords: $\quad$ Sanitation Hygiene, Maternal Education, Toddler Diarrhea, Karyajaya Village

\section{PENDAHULUAN}

Penyakit diare menjadi permasalahan utama di negara-negara berkembang termasuk di Indonesia. Selain sebagai penyebab kematian, diare juga menjadi penyebab utama gizi kurang yang bisa menimbulkan kematian serta dapat menimbulkan kejadian luar biasa. Beberapa faktor yang menjadi penyebab timbulnya penyakit diare disebabkan oleh bakteri melalui kontaminasi makanan dan minuman yang tercemar tinja dan atau kontak langsung dengan penderita (Nugraheni, 2014).

Selain itu, faktor yang paling dominan berkontribusi dalam penyakit diare adalah air, higiene sanitasi, jamban keluarga, dan air (Mulyani, 2015). Jarak sumber air minum, ketersediaan dan kepemilikan jamban menjadi faktor risiko penyebab diare. Diare berhubungan dengan sanitasi yang tidak memadai dan pola higiene yang buruk (Astuti, 2015).

Anak adalah investasi bangsa karena mereka adalah generasi penerus 
bangsa. Kualitas bangsa di masa depan ditentukan oleh kualitas anak-anak saat ini. Gangguan kesehatan yang terjadi pada masa anak-anak dapat mempengaruhi proses tumbuh kembang anak, khususnya jika gangguan tersebut terjadi pada saluran pencernaan yang mempunyai peranan penting dalam penyerapan nutrisi yang diperlukan untuk menunjang tumbuh kembang anak. Salah satu gangguan pada saluran pencernaan yang sering terjadi pada anak balita adalah diare.

Penelitian yang dilakukan oleh Ferllando (2014) di Puskesmas Mangkang Kota Semarang mengenai faktor risiko penyebab diare ditemukan bahwa faktor lingkungan terkait perilaku hidup masyarakat yang kurang baik dan kondisi lingkungan yang buruk menjadi penyebab seseorang mudah terserang penyakit diare. Seiring dengan hal ini, penelitian yang dilakukan oleh Nurpauji (2015) di Puskesmas Lamper Tengah Semarang mengenai sanitasi lingkungan terkait penyakit diare pada balita, ditemukan bahwa jenis sumber air untuk minum dan perilaku ibu dalam mengelola makanan dan minuman dapat berpengaruh terhadap tingginya angka diare pada balita.
Penggunaan air harus memenuhi persyaratan fisik, kimia dan biologis. Kualitas air secara bakteriologis tidak boleh mengandung bakteri (Kemenkes RI, 2015). Indikator mikroorganisme pada air adalah bakteri coliform yang umumnya ditemui pada usus manusia dan hewan (Viessman and Hammer, 2005).

Beberapa sarana air yang biasa digunakan dalam memperoleh air antara lain Penampungan Air Hujan (PAH), Perlindungan Mata Air (PMA), sumur gali dan PDAM. Air dari sumber dapat tercemar oleh berbagai aktifitas manusia diantaranya cemaran dari septictank, saluran limbah dan pembuangan sampah (Kementerian Kesehatan Republik Indonesia, 2015).

Penelitian yang dilakukan oleh Carrel (2011) di Bangladesh ditemukan bahwa sarana air bersih memiliki hubungan dengan kejadian diare, dimana penyimpanan air dengan cara yang tidak benar dapat menyebabkan air terkontaminasi mikroba yang dapat menyebabkan diare dan pasokan air yang kurang juga menjadi penyebab diare, sebab penggunaan air menjadi terbatas. Penelitian lainnya yang dilakukan oleh Gallas (2007) di Meksiko dilaporkan bahwa 
mikroorganisme patogen penyebab diare adalah bakteri coliform dan E.coli, dimana kasus diare meningkat pada musim libur karena peningkatan paparan dari lingkungan dan kontaminasi makanan.

Secara global setiap tahunnya ada sekitar 2 miliar kasus diare dengan angka kematian 1,5 juta per tahun. Berdasarkan Profil Kesehatan Indonesia tahun 2015, terjadi 18 kali KLB diare yang tersebar di 11 provinsi, 18 kabupaten/kota, dengan jumlah penderita 1.213 orang dan kematian 30 orang (CFR 2,47\%). Angka kesakitan nasional hasil Survei Morbiditas Diare tahun 2015 yaitu sebesar 214/1.000 penduduk. Maka diperkirakan jumlah penderita diare di fasilitas kesehatan sebanyak 5.097.247 orang, sedangkan jumlah penderita diare yang dilaporkan ditangani di fasilitas kesehatan sebanyak 4.017.861 orang atau 74,33\% (dengan target 100\%) (Kemenkes RI, 2015). Sedangkan tahun 2016, perkiraan diare di fasilitas kesehatan meningkat sebanyak 6.897 .463 orang dan diare yang ditangani di fasilitas kesehatan sebanyak 2.544.084 orang atau 36,9\% (Kementerian Kesehatan RI, 2016).

Selain itu, penyakit diare sering menyerang bayi dan balita, bila tidak diatasi lebih lanjut diare akan menyebabkan dehidrasi yang mengakibatkan kematian. Diare menjadi pembunuh nomor satu penyebab kematian berdasarkan umur pada anak balita atau kelompok umur 7-59 bulan (Kementerian Kesehatan RI, 2016).

Menurut Profil Kesehatan Kota Palembang tahun 2015, diketahui bahwa sepuluh penyakit terbanyak pada kunjungan rawat jalan puskesmas Kota Palembang didominasi penyakit infeksi dan penyakit menular. Dari data kasus diare, adanya peningkatan cakupan penemuan diare dari tahun 2011 (76,19\%), 2012 (94,27\%), 2013 (150,54\%), $2014(155,72 \%)$, tetapi pada tahun 2015 cakupan penemuan diare sedikit menurun yaitu $110,53 \%$ (Dinas Kesehatan Kota Palembang, 2015). Dan kembali meningkat pada tahun 2016 sebesar $114,48 \%$ atau 38.721 kasus diare dimana $57,2 \%$ terjadi pada balita (Dinas Kesehatan Kota Palembang, 2016).

Di Kecamatan Kertapati, jumlah kasus diare yang dilaporkan dari puskesmas pada tahun 2016 yaitu sebanyak 811 kasus dengan angka insiden pada balita sebanyak 704 kasus $(57,7 \%)$. Dari tiga kelurahan yang ada di Kecamatan Kertapati, Kelurahan 
Karya Jaya merupakan kelurahan yang paling padat pemukimannya dan paling banyak penduduknya dibandingkan dengan Kelurahan Keramasan dan Kertapati. Selain itu, masyarakat Kelurahan Karya Jaya memiliki cakupan rumah yang memenuhi syarat rumah sehat baru mencapai 30,50\%, akses sanitasi layak di Kelurahan Karya Jaya baru mencapai $43,71 \%$ dan akses air minum layak baru mencapai 21,02\% (Puskesmas Karya Jaya, 2016).

Dengan memperhatikan data-data tersebut, maka dilakukan penelitian mengenai hubungan sarana sanitasi lingkungan dan perilaku ibu terhadap kejadian diare pada balita di Kelurahan Karya Jaya Kota Palembang.

\section{METODE PENELITIAN}

\section{Desain dan Sampel}

Penelitian yang akan dilakukan menggunakan metode kuantitatif, dengan desain studi cross sectional. Rancangan survey cross sectional adalah suatu penelitian untuk mempelajari dinamika kolerasi antara faktor-faktor dengan efek, dengan cara pendekatan, observasi, atau pengumpulan data sekaligus pada suatu saat (point time approach).

Besar sampel dihitung dengan menggunakan rumus besar sampel desain cross sectional menggunakan rumus Lemeshow, yaitu :

$$
\begin{aligned}
& n=\frac{\left(z_{1-\propto \sqrt{2 \overline{P(1-\bar{P})}}+z_{1-\beta} \sqrt{P_{1}\left(1-P_{1}\right)+P_{2}\left(1-P_{2}\right)}}^{)^{2}}\right.}{\left(P_{1-} P_{2}\right)^{2}} \\
& n=\frac{(1,96 \sqrt{0,6(0,7)}+1,64 \sqrt{0,5(0,5)+0,1(0,9)})^{2}}{0,16} \\
& n=27,2
\end{aligned}
$$

Jadi jumlah sampel yang didapatkan adalah 27,2 dikalikan 2 menjadi 54,4 sampel.

Keterangan :

$$
\begin{array}{ll}
\mathrm{n} & : \text { Jumlah Sampel } \\
\mathrm{Z} 1-\alpha / 2 & : \text { Derivat baku alpha } 5 \%=1,96 \\
\mathrm{Z} 1-\beta & : \text { Derivat baku beta kekuatan uji } \\
& 95 \%=1,64 \\
\mathrm{P} & : \text { Rata-rata proporsi }((\mathrm{P} 1+\mathrm{P} 2) \\
& : 2=0,3) \\
\mathrm{P} 1 & : \text { Proporsi hubungan kondisi } \\
& \text { sanitasi lingkungan yang tidak } \\
& \text { memenuhi syarat terhadap } \\
& \text { kejadian diare balita 50\% }(0,5) \\
& \text { (Kamila, 2013). } \\
& : \text { Proporsi hubungan kondisi } \\
\text { P2 } & \text { sanitasi lingkungan yang } \\
& \text { memenuhi syarat terhadap } \\
& \text { kejadian diare balita 10\% }(0,1) \\
& \text { (Kamila, 2013). }
\end{array}
$$

Dari rumus di atas didapatkan sampel sebanyak 54,4 sampel, untuk menghindari drop out dan missing data maka akan dilakukan penambahan $10 \%$. Penggunaan drop out adalah untuk mengantisipasi apabila terdapat data sampel yang tidak sesuai atau tidak terisi yang menyebabkan data sampel dibuang, sehingga besar sampel menjadi 59,8 dibulatkan menjadi 60 sampel. 


\section{Prosedur Penelitian}

Pengumpulan data variabel bebas dan terikat dengan menggunakan kuesioner dan pengujian laboratorium. Kuesioner terdiri atas biodata responden terkait pendidikan ibu, pemberian ASI Eksklusif, higiene sanitasi makanan dan minuman, dan kejadian diare balita. Kuesioner yang dibuat terlebih dahulu divalidasi dan harus reliabel sebelum dilakukan penelitian.

\section{Analisis Data}

Data dianalisis dan diinterpretasikan untuk menguji hipotesis yang diajukan dengan menggunakan program komputer univariat, bivariat dan multivariat. Analisis univariat untuk memperoleh gambaran masing-masing variabel independen dan variabel dependen. Data yang disajikan dalam bentuk tabel frekuensi untuk mendapatkan gambaran responden menurut karakteristik dalam bentuk analisa univariat.

Analisis bivariat dalam penelitian ini adalah menganalisis silang dua variabel yaitu variabel independen dengan variabel dependen. Analisis ini dilakukan untuk melihat kemaknaan hubungan independen dengan dependen dengan menggunakan Uji Chi Square $\left(\mathrm{X}^{2}\right)$ dengan menggunakan $\alpha=0,05$ dan
95\% Confidence Interval/CI (logika dasar kepercayaan). Dasar pengambilan keputusan penerimaan hipotesis berdasarkan tingkat signifikan (nilai $\alpha$ ) sebesar $95 \%$.

Analisis multivariate regresi logistik ganda merupakan pendekatan analisis statistik melalui model matematik yang digunakan untuk menjelaskan hubungan antara beberapa variabel independen dan variabel dependen yang biner (binary variable). Model regresi logistik untuk menghitung nilai OR (Odds Ratio) yang merupakan perhitungan RR yang indirect. Analisis regresi logistik ganda digunakan untuk mengetahui variabel yang dianggap terbaik untuk memprediksi variabel dependen.

Tabel 1 Distribusi Frekuensi Karakteristik Masyarakat

\begin{tabular}{|c|c|c|c|}
\hline No & Variabel & $\mathbf{n}$ & $\%$ \\
\hline \multirow[t]{4}{*}{1.} & Tingkat Pendidikan & & \\
\hline & Ibu & 45 & 75 \\
\hline & Rendah & 15 & 25 \\
\hline & Tinggi & & \\
\hline \multirow[t]{3}{*}{2.} & Pemberian ASI & & \\
\hline & Eksklusif & 38 & 63,3 \\
\hline & $\begin{array}{l}\text { Tidak ASI Eksklusif } \\
\text { ASI Eksklusif }\end{array}$ & 22 & 36,7 \\
\hline \multirow[t]{5}{*}{3.} & Higiene Sanitasi & & \\
\hline & Makanan dan & 42 & 70 \\
\hline & Minuman & 18 & 30 \\
\hline & Buruk & & \\
\hline & Baik & & \\
\hline \multirow[t]{3}{*}{4} & Kejadian Diare Balita & & \\
\hline & Diare & 47 & 78,3 \\
\hline & Tidak Diare & 13 & 21,7 \\
\hline Jumlah & & 60 & $100 \%$ \\
\hline
\end{tabular}




\section{Analisis Bivariat}

Tabel 2 Hubungan Pendidikan Ibu Dengan Kejadian Diare Balita

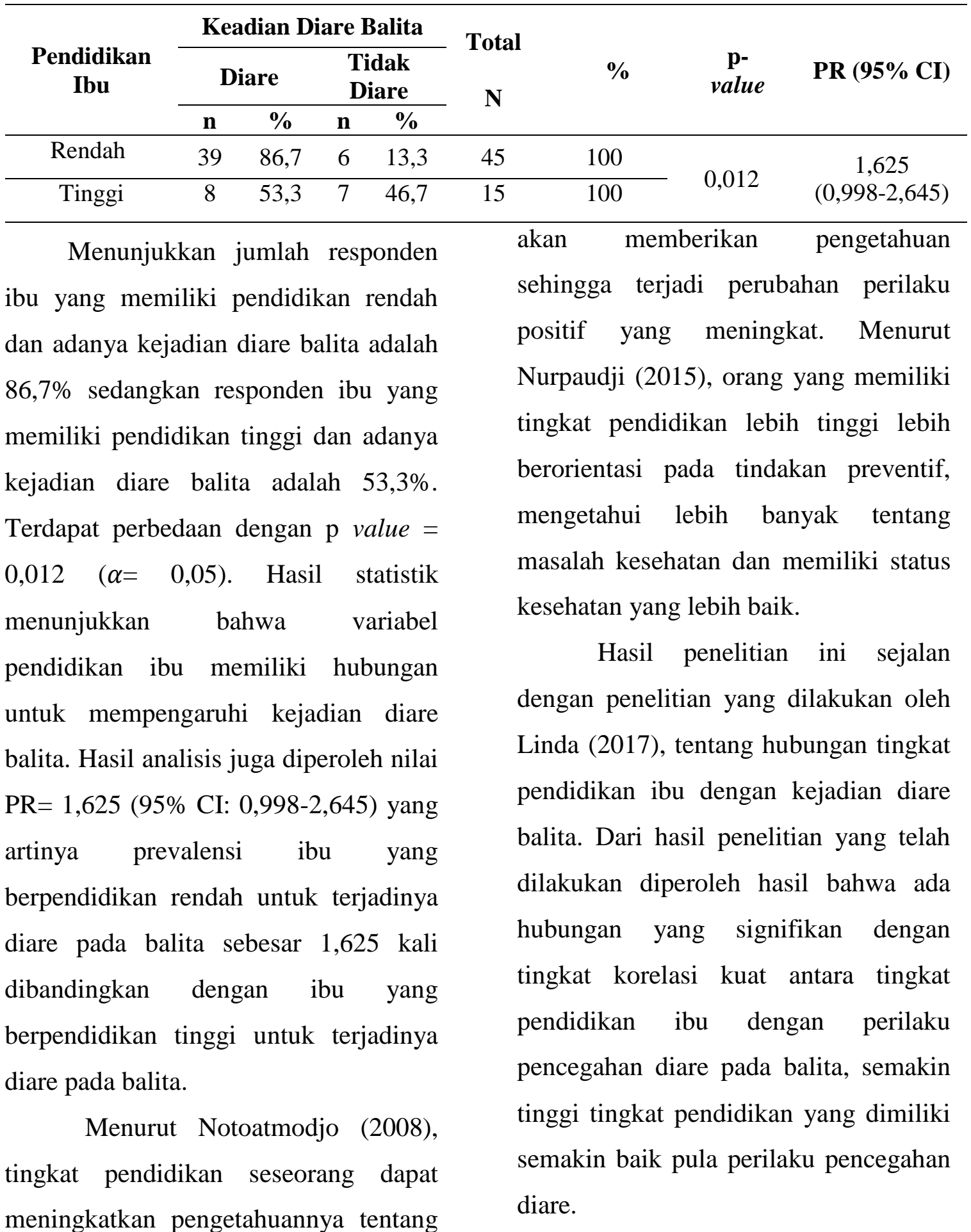

kesehatan. Salah satu faktor yang mempengaruhi pengetahuan seseorang adalah tingkat pendidikan. Pendidikan 
Tabel 3 Hubungan Pemberian ASI Eksklusif Dengan Kejadian Diare Balita

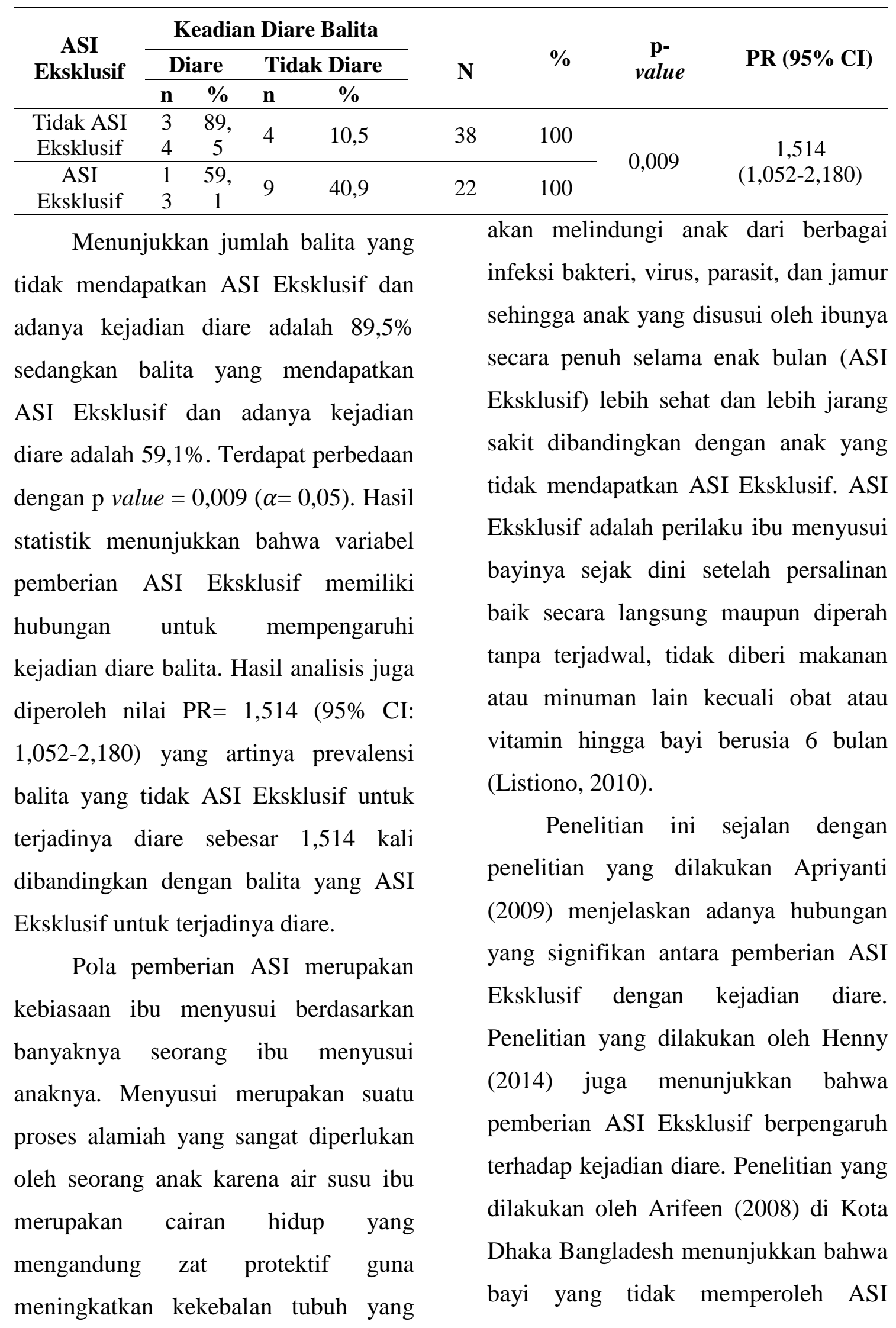


Eksklusif berhubungan dengan dengan bayi yang memperoleh ASI kematian akibat diare dengan resiko Eksklusif.

3,94 kali lebih besar dibandingkan

Tabel 4 Hubungan Higiene Sanitasi Makanan dan Minuman dengan Kejadian Diare Balita

\begin{tabular}{|c|c|c|c|c|c|c|}
\hline \multirow{3}{*}{$\begin{array}{c}\text { Higiene } \\
\text { Sanitasi } \\
\text { Makanan } \\
\text { dan }\end{array}$} & \multicolumn{2}{|c|}{ Keadian Diare Balita } & \multirow{2}{*}{ Total } & \multirow[b]{2}{*}{$\%$} & \multirow{2}{*}{$\begin{array}{c}\text { p- } \\
\text { valu }\end{array}$} & \multirow{3}{*}{ PR $(95 \%$ CI $)$} \\
\hline & Diare & Tidak Diare & & & & \\
\hline & $\%$ & $\%$ & $\mathbf{N}$ & & $e$ & \\
\hline
\end{tabular}

\begin{tabular}{ccccccccc}
\hline Buruk & 40 & 95,2 & 2 & 4,8 & 42 & 100 & \multirow{2}{*}{0,00} & $\begin{array}{c}2,449 \\
(1,367-4,387)\end{array}$ \\
\hline Baik & 7 & 38,9 & 11 & 61,1 & 18 & 100 & & (1,36)
\end{tabular}

Menunjukkan higiene sanitasi

makanan dan minuman buruk dengan adanya kejadian diare adalah $95,2 \%$, sedangkan higiene sanitasi makanan dan minuman baik dengan adanya kejadian diare adalah $38,9 \%$. Terdapat perbedaan dengan p value $=0,000(\alpha=0,05)$. Hasil statistik menunjukkan bahwa variabel higiene sanitasi makanan dan minuman memiliki hubungan untuk mempengaruhi kejadian diare balita. Hasil analisis juga diperoleh nilai $\mathrm{PR}=$ $2,449 \quad(95 \%$ CI: $1,367-4,387)$ yang artinya prevalensi higiene sanitasi makanan dan minuman buruk untuk terjadinya diare sebesar 2,449 kali dibandingkan dengan higiene sanitasi makanan dan minuman baik untuk terjadinya diare.

Higiene sanitasi makanan dan minuman penting dilakukan untuk mencegah terjadinya kontaminasi yang dapat menimbulkan gangguan keehatan.
Bakteri adalah zat pencemar yang terdapat pada makanan. Penularan dari agen patogen dapat terjadi melalui proses penanganan makanan minuman meliputi peralatan, proses pencucian, penyimpanan dan penyajian makanan. Air harus dimasak sampai mendidih sehingga mikroba patogen mati. Makanan dimasak menggunakan panas yang cukup sehingga matang dengan sempurna sampai ke bagian dalamnya. Suhu yang berbahaya adalah $10-60$ derajat celcius, karena dapat menyuburkan pertumbuhan mikroorganisme. Pemasakan yang tidak sempurna dapat menimbulkan penyakit. Pemanasan ulang harus dilakukan sempurna sehingga bagian dalam dari masakan mecapai titik didih dan biarkan selama 2 menit setelah mendidih (Kementerian Kesehatan RI, 2010).

Rendahnya pendidikan dan ketidakperdulian mengakibatkan 
kesalahan dalam penanganan dan menyiapkan makanan dan minuman. Penelitian ini sejalan dengan penelitian Hidayanti (2012), menyebutkan bahwa adanya hubungan antara higiene sanitasi makanan dan minuman terhadap tingginya anga diare. Peralatan yang digunakan untuk bahan makanan dengan makanan jadi sebaiknya dipisah untuk menghindari kontaminasi silang. Tempat pengolahan makanan sebaiknya di meja yang bebas dari kotoran dan bukan dilantai, penanganan makanan di tanah atau lantai dapat terkontaminasi oleh kotoran atau debu dan mikroba pathogen sehingga makanan tercemar.

\section{Analisis Multivariat}

\section{Seleksi Bivariat}

Tahap awal seleksi bivariat yaitu pemilihan kandidiat multivariat yang meliputi pendidikan ibu, pemberian ASI Eksklusif, dan higiene sanitasi makanan dan minuman. Jika analisa bivariat menghasilkan $\mathrm{p}$ value $<0,25$ maka variabel tersebut masuk ke permodelan multivariat. Hasil seleksi bivariat pada penelitian ini dapat dilihat pada tabel berikut.
Tabel 5 Hasil Seleksi Bivariat

\begin{tabular}{lc}
\hline \multicolumn{1}{c}{ Variabel } & p value \\
\hline Pendidikan Ibu & 0,010 \\
Pemberian ASI & 0,010 \\
Eksklusif & \\
Higiene Sanitasi & 0,000 \\
Makanan dan & \\
Minuman & \\
\hline
\end{tabular}

\section{Permodelan Multivariat}

Analisis multivariat dalam penelitian ini menggunakan metode ENTER. Metode ENTER adalah semua variabel yang memiliki nilai $p$-value > 0,05 dikeluarkan secara bertahap, sehingga kita membuat urutan variabel yang mempunyai nilai $\mathrm{p}$ yang paling besar untuk dikeluarkan terlebih dahulu dari model pada proses regresi logistik.

Tahap selanjutnya yaitu melihat perubahan nilai OR dengan menggunakan rumus Perubahan OR = (OR sebelum variabel terpilih dikeluarkan - OR setelah variabel terpilih dikeluarkan) dibagi OR setelah variabel terpilih dikeluarkan dikali 100 $\%$. Jika terdapat perubahan nilai OR yang dihasilkan $\geq 10 \%$, maka variabel tersebut tetap berada didalam model, karena merupakan variabel confounding, namun bila perubahan nilai OR yang dihasilkan $\leq 10 \%$, maka variabel tersebut harus dikeluarkan dari 
model karena bukan variabel confounding.

Adapun tahapan proses regresi logistik berganda dan perubahan nilai OR disajikan pada tabel di bawah ini:

\begin{tabular}{lllll} 
Tabel 6 & $\begin{array}{l}\text { Model Akhir } \\
\text { Logistik Ganda }\end{array}$ & Regresi \\
\hline Variabel & SE & Sig & Exp & $\mathbf{9 5 \%}$
\end{tabular}

(B) $\quad$ CI

\begin{tabular}{lcccc}
\hline $\begin{array}{l}\text { Pendidikan } \\
\text { Ibu }\end{array}$ & 0,97 & 0,394 & 2,304 & $0,339-$ \\
& & & & 15,674 \\
$\begin{array}{l}\text { Pemberian } \\
\text { ASI }\end{array}$ & 0,93 & 0,115 & 4,388 & $\begin{array}{c}0,699- \\
27,566\end{array}$ \\
$\begin{array}{l}\text { Eksklusif } \\
\text { Higiene }\end{array}$ & & & & \\
$\begin{array}{l}\text { Sanitasi } \\
\text { Makanan } \\
\text { dan } \\
\text { Minuman }\end{array}$ & 0,95 & 0,003 & 16,55 & $\begin{array}{c}2,525- \\
108,476\end{array}$ \\
\hline
\end{tabular}

Berdasarkan tabel diatas adalah model terakhir (analisis multivariat) didapatkan nilai yang bermakna dengan $\mathrm{OR}=16,550(95 \% \mathrm{CI}: 2,525-108,476)$ dengan nilai $\mathrm{p}=0,003$ pada variabel higiene sanitasi makanan dan minuman artinya dengan higiene sanitasi makanan dan minuman yang buruk beresiko untuk terjadinya diare pada balita dibandingkan dengan responden yang memiliki higiene sanitasi makanan dan minuman yang baik.

\section{KESIMPULAN DAN SARAN}

\section{Kesimpulan}

Hasil penelitian didapatkan bahwa ada hubungan bermakna antara pendidikan ibu, pemberian ASI Eksklusif, dan hygiene sanitasi makanan dan minuman terhadap kejadian diare balita. Berdasarkan hasil multivariat variabel pada penelitian ini, variabel hygiene sanitasi makanan dan minuman merupakan variabel paling dominan yang mempengaruhi diare balita.

\section{Saran}

1. Peningkatan upaya penyuluhan kepada masyarakat terutama ibu balita tentang pentingnya upaya peningkatan gizi balita, perawatan kesehatan dan pertumbuhan balita, penggunaan air bersih yang memenuhi syarat, penggunaan jamban keluarga yang memenuhi syarat, serta perilaku pencegahan yang dapat menghindari balita dari terkena diare.

2. Pelatihan petugas tentang tumbuh kembang balita, peningkatan status gizi serta metode pendidikan kebersihan perorangan dan kebersihan lingkungan.

3. Program kaporisasi pada sarana air bersih yang digunakan penduduk. 
4. Kepada Dinas Kesehatan agar melakukan pengawasan di berbagai kelurahan di Kota Palembang dalam menurunkan angka kejadian diare pada balita.

\section{DAFTAR PUSTAKA}

Achmadi. 2010. Manajemen Penyakit Berbasis Wilayah. Jurnal Kesehatan Masyarakat Nasional. Vol 3 (4): 12-21.

Apriyanti, 2009. Hubungan antara Hygiene Makanan dengan kejadian diare Pada penduduk di kelurahan oesapa kecamatan kelapa lima Kota kupang. Tesis Universitas Nusa Cendana. Nusa Tenggara Timur.

Arifeen, S., 2008. Exclusive Breastfeeding Reduces Acute Resporatory Infection and Diarrhea Deaths Among Infants in Dhaka Slums. Journal of The American Academy of Pediatrics. Vol. 108 (4): 32-45.

Astuti, I. P., 2015. Faktor-faktor yang Berhubungan dengan Kejadian Diare di Wilayah Kerja Puskesmas Tengal Angus Kabupaten Tangerang. Jurnal Kesehatan Lingkungan. Vol. 10 (XVIII): 89-103.

Carrel, 2011. Diarrheal disease risk in rural Bangladesh decreases as tubewell density increases: a zero-inflated and geographically weighted analysis. World Journal of Environmental Biosciences. Vol. 11 (4): 4-12.

Dinas Kesehatan Kota Palembang. 2015. Profil Kesehatan Kota Palembang. Palembang.
2016. Profil Kesehatan Kota

Palembang Tahun 2016. Palembang.

Ferllando, H. T., 2014. Hubungan Antara Sanitasi Lingkungan dan Personal Higiene dengan Kejadian Diare di Wilayah Kerja Puskesmas Mangkang. Artikel Ilmiah Universitas Dian Nuswantoro Semarang.

Gallas, A. N., 2007. Etiology of acute diarrhea in children and adults in Tunis, Tunisia, with emphasison diarrheagenic Escherichia coli: prevalence, phenotyping, and moleculer epidemiology. American Journal Tropical Medicine Higiene.

Henny, 2014. Hubungan Pemberian ASI Eksklusif dengan Kejadian Diare pada Anak Usia 12-24 Bulan di Puskesmas Terjun Medan. Jurnal Ilmiah Kesehatan Semarang. Vol. 2 (6): 30-45.

Hidayanti, R., 2012. Faktor Risiko Diare di Kecamatan CIsarua, Cigudeg dan Megamendung Kabupaten Bogor. Jurnal Kesehatan Lingkungan Universitas Indonesia.

Kementerian Kesehatan Republik Indonesia. 2011. Buku Pedoman Pengendalian Penyakit Diare. Direktorat Jenderal Pengendalian Penyakit \& Penyehatan Lingkungan. Jakarta. . 2014. Situasi Diare di Indonesia. Buletin Jendela, Data dan Informasi Kesehatan. Jakarta.

2015. Profil Kesehatan Indonesia 2015. Jakarta.

2016. Profil Kesehatan Indonesia 2016. Jakarta. 
Kamila, L., 2013. Hubungan Praktek Personal Higiene Ibu dan Kondisi Sanitasi Lingkungan Rumah dengan Kejadian Diare pada Balita di Puskesmas Kampung Dalam Kecamatan Pontianak Timur. Jurnal Kesehatan Lingkungan Indonesia. Vol. 11 (2): 211-223.

Linda, A., 2017. Faktor-faktor yang Berhubungan dengan Diare pada Balita di Wilayah Kerja Puskesmas Harapan Baru Kecamatan Loa Janan Ilir Kota Samarinda. Kesmas Wigama Jurnal Kesehatan Masyarakat. Vol 03 (02): 98-106

Listiono, 2010. Faktor-faktor yang Berhubungan dengan Kejadian Diare di Wilayah Kerja Puskesmas Lebakwangi Kecamatan Cigudeg Kabupaten Bogor. Fakultas Kesehatan Masyarakat Universitas Indonesia.

Mulyani, N. S., 2015. Faktor Risiko Diare Akut pada Balita. Berita Kedokteran Masyarakat. Vol 27 (1): 55-81.

Nugraheni, D., 2014. Hubungan Kondisi Fasilitas Sanitasi Dasar dan Personal Higiene dengan Kejadian Diare di Kecamatan Semarang Utara. Jurnal Kesehatan Masyarakat. Vol.1 (2): 17-25.
Nurpauji, S. V., 2015. Hubungan Jenis Sumber Air, Kualitas Bakteriologis Air, Personal Higiene Dengan Kejadian DIare Pada Balita di Wilayah Kerja Puskesmas Lamper Tengah Semarang. Jurnal Kesehatan Masyarakat FKM Undip Vol. 3 (2).

Peraturan Menteri Kesehatan Nomor 892/ MENKES/ SK/VII/1999 tentang Persyaratan Rumah Sehat. Departemen Kesehatan Republik Indonesia. Jakarta.

Peraturan Menteri Kesehatan Nomor 492/Menkes/PER/IV/2010 tentang Standar Baku Mutu Kesehatan Lingkungan dan Persyaratan Kesehatan Air Untuk Keperluan Higiene Sanitasi, Kolam Renang, Solus Per Aqua, dan Pemandian Umum. Kementerian Kesehatan Republik Indonesia. Jakarta.

Puskesmas Karya Jaya. 2016. Profil Kesehatan Puskesmas Karya Jaya.

Viessman, J. W. and Hammer, M. J., 2005. Water supply and pollution control. Person Educational International.

World Health Organization. 2011. Guidelines for drinking water quality. 